\title{
Simultaneous Removal of MTBE and Benzene from Contaminated Groundwater Using Ultraviolet-Based Ozone and Hydrogen Peroxide
}

\author{
Bassam S. Tawabini \\ Earth Sciences Department, King Fahd University of Petroleum \& Minerals, P.O. Box 189, Dhahran 31261, Saudi Arabia \\ Correspondence should be addressed to Bassam S. Tawabini; bassamst@kfupm.edu.sa
}

Received 30 March 2014; Revised 1 May 2014; Accepted 1 May 2014; Published 19 May 2014

Academic Editor: Leonardo Palmisano

Copyright (c) 2014 Bassam S. Tawabini. This is an open access article distributed under the Creative Commons Attribution License, which permits unrestricted use, distribution, and reproduction in any medium, provided the original work is properly cited.

Efficiency of ultraviolet-ozone $\left(\mathrm{UV} / \mathrm{O}_{3}\right)$ and ultraviolet-hydrogen peroxide $\left(\mathrm{UV} / \mathrm{H}_{2} \mathrm{O}_{2}\right)$ processes was investigated for simultaneous removal of methyl tertiary butyl ether (MTBE) and benzene from contaminated ground water. The photoreactor employed housed 15-watt low pressure (LP) and 150-watt medium pressure (MP) mercury UV lamps. Oxidation of contaminants was studied at two different levels of ozone and hydrogen peroxide. Brackish groundwater samples were spiked with MTBE and benzene up to a concentration of $500 \mu \mathrm{g} \mathrm{L}{ }^{-1}$. Removal potential was evaluated at different parameters such as UV type and intensity and peroxide and ozone dosages, as well as contact time. Results indicated that no removal of the contaminants was attained when treated with hydrogen peroxide or ozone alone. However, about 50\% and 30\% removal of MTBE were achieved in 30 minutes when irradiated with MP-UV and LP-UV lamps, respectively. On the other hand, $\mathrm{UV} / \mathrm{H}_{2} \mathrm{O}_{2}$ process was found to be superior in removal of MTBE ( $90 \%$ in $10 \mathrm{~min}$.) and benzene ( $95 \%$ in $5 \mathrm{~min}$.) compared to $\mathrm{UV} / \mathrm{O}_{3}$ process. Furthermore, removal of benzene was comparatively easier than MTBE in both approaches. It is hence concluded that higher UV intensities and elevated doses of $\mathrm{H}_{2} \mathrm{O}_{2}$ accelerate simultaneous removal of MTBE and benzene from water.

\section{Introduction}

In oil producing countries, contamination of water resources is generally attributed to fuel additives and different fuel products. These contaminants reach water bodies through different routes such as the process of transportation, mixing, refining, and filling operations. Fuel products such as benzene, toluene ethyl benzene, and xylenes (BTEX) and fuel additives such as methyl tert-butyl ether (MTBE) are among the organic pollutants commonly detected in water resources. MTBE is added to fuel to enhance the octane number and reduce air emissions of carbon monoxide since the issuance of US Clean Air Act (USCAA) in 1970s [1]. Major causes of MTBE pollution are leakages in underground storage tanks and pipelines and accidental spills during refining processes. Many studies have reported their presence and impacts in atmosphere [2] as well as in groundwater [3]. Toxicity analysis conducted on test animals has shown that direct exposure to MTBE, even for shorter periods of time, can cause nausea, vomiting, and sleepiness [3].
On the other hand, benzene has received a lot of attention due to its carcinogenic nature [4]. It has been reported that, in drinking water, more than $0.005 \mathrm{mg} / \mathrm{L}$ of benzene can seriously increase the risk of cancer [5]. Benzene concentration in gasoline is being regulated at $1 \%$ by volume that renders it harmful carcinogen for living organism. Studies conducted on animal models show that benzene toxicity can increase the chances of cancer mutagenesis at $\mathrm{p} 53$ gene which results into uncontrolled growth of cells [6].

Despite the fact that both MTBE and benzene may exist together, they have different physical and chemical characteristics which affect their transportation and fate in the environment. For example, solubility of MTBE in water bodies is 20 times higher $\left(43,000-54,300 \mathrm{mg} \mathrm{L}^{-1}\right)$ than benzene (1780 $\mathrm{mg} \mathrm{L}^{-1}$ ) and other compounds in BTEX [7]. This enhances the movement of MTBE in underground formations and renders it difficult to trace. Furthermore, lower $K_{\mathrm{oc}}$ and $K_{\mathrm{ow}}$ values of MTBE indicate its lesser ability for adsorption to solid particles than benzene [8]. 
A number of techniques have been employed for the removal of MTBE and benzene from contaminated water. Bioremediation has not been very successful due to low biomass production and slow growth kinetics of bacteria [9]. Furthermore, air stripping has been reported by some researchers as a noneconomical technique for MTBE removal from water [9] and adsorption to granular activated carbon (GAC) or synthetic resins only leads to transfer of MTBE from one phase to another instead of remediation. However, superior results in removal of MTBE have been reported by employing advanced oxidation processes (AOPs) [10, 11]. Commonly used AOPs include the use of ozone-hydrogen peroxide oxidation $\left(\mathrm{O}_{3} / \mathrm{H}_{2} \mathrm{O}_{2}\right)$, UV-hydrogen peroxide oxidation $\mathrm{UV} / \mathrm{H}_{2} \mathrm{O}_{2}$, ultrasonic ozonation $\left(\mathrm{O}_{3}\right)$, Fenton and photo-Fenton reactions, and photocatalysis with titanium dioxide $\left(\mathrm{TiO}_{2}\right)[9,12,13]$. These processes generate highly reactive hydroxyl radicals $\left(\mathrm{OH}^{\circ}\right)$ that in turn react with the contaminants and degrade them. Under optimum conditions, these hydroxyl radicals can completely mineralize the organic pollutants to their basic constituents, carbon dioxide and water [9]. Systems coupled with $\mathrm{O}_{3} / \mathrm{H}_{2} \mathrm{O}_{2}$ possess great potential to degrade high amount of MTBE from water than $\mathrm{O}_{3}$ and $\mathrm{H}_{2} \mathrm{O}_{2}$. However, the only disadvantage found in the system is the capability for bromate formation through adjustment of $\mathrm{H}_{2} \mathrm{O}_{2} / \mathrm{O}_{3}$ ratio [9]. Benzene has also been removed by using modern techniques such as $\mathrm{UV} / \mathrm{H}_{2} \mathrm{O}_{2}[14]$ and photocatalytic process of $\mathrm{UV} / \mathrm{TiO}_{2}$ [15]. Likewise, other studies have also reported the photocatalytic degradation of gaseous benzene over UV-irradiated $\mathrm{TiO}_{2}$ nanoballs [16, 17]. A system possesses higher efficiency of degradation than $\mathrm{O}_{3}$ or UV alone but requires high cost and energy sometimes [9].

However, there is lack of convincing data for simultaneous removal of both benzene and MTBE using AOPs, despite the fact that both contaminants have quite often been found together in industrial wastes [18]. Therefore, the main objective of this study was to evaluate the efficacy of AOPs in simultaneous removal of benzene and MTBE from contaminated water.

\section{Materials and Methods}

2.1. Solutions. A control solution was prepared from deionized water. Highly pure (>99.5\%) MTBE and benzene were obtained from Sigma-Aldrich (UK). Stock standard solutions of $100 \mathrm{ppm}$ of MTBE and benzene were prepared in deionized water and spiked to initial concentration of about $500 \mathrm{ppb}$.

A test solution was prepared from groundwater samples that were collected from a well located in Dhahran, Saudi Arabia. The well has a total depth of $180 \mathrm{~m}$ and taps Umm er Radhuma (UER) aquifer. The well, being pumped at an average rate of about 1000 gallons $\mathrm{min}^{-1}$, is mainly used for domestic cleansing and toilet flushing purposes. Chemical analysis of groundwater was performed to determine levels of dissolved salts (Table 1). Both MTBE and benzene were not detected in the raw water samples and hence were spiked at concentrations of $500 \mathrm{ppb}$.

Hydrogen peroxide $\left(\mathrm{H}_{2} \mathrm{O}_{2}\right)$ of approximately $35 \%$ purity, purchased from local market, was used to prepare the stock
TABLE 1: Characteristics of groundwater samples.

\begin{tabular}{lc}
\hline Parameters & Value \\
\hline $\mathrm{pH}$ & 7.09 \\
$\mathrm{TDS}, \mathrm{mg} / \mathrm{L}$ & 3645 \\
D.O., mg/L & 5.78 \\
Turbidity, NTU & 0.1 \\
$\mathrm{TSS} \mathrm{mg} / \mathrm{L}$ & 5.0 \\
$\mathrm{TOC} \mathrm{mg} / \mathrm{L}$ & 5.36 \\
$\mathrm{MTBE} \mu \mathrm{g} / \mathrm{L}$ & $<1.0$ \\
$\mathrm{VOC} \mu \mathrm{g} / \mathrm{L}$ & $<1.0$ \\
$\mathrm{BTEX}^{\mathrm{g}} / \mathrm{L}$ & $<1.0$ \\
$\mathrm{Alkalinity-T}^{-}\left(\mathrm{CaCO}_{3}\right)$ & 433.5 \\
$\mathrm{Cl}^{-} \mathrm{mg} / \mathrm{L}$ & 1220.38 \\
$\mathrm{NO}_{3}^{--} \mathrm{mg} / \mathrm{L}$ & 3.809 \\
$\mathrm{Br}^{-} \mathrm{mg} / \mathrm{L}$ & 4.212 \\
$\mathrm{SO}_{4}{ }^{--} \mathrm{mg} / \mathrm{L}$ & 545.69 \\
$\mathrm{Ca}^{++} \mathrm{mg} / \mathrm{L}$ & 255.1 \\
$\mathrm{Fe}^{+} \mathrm{mg} / \mathrm{L}$ & $<0.009$ \\
$\mathrm{~K}^{+} \mathrm{mg} / \mathrm{L}$ & 34.2 \\
$\mathrm{Mg}^{++} \mathrm{mg} / \mathrm{L}$ & 82.5 \\
$\mathrm{Na}^{+} \mathrm{mg} / \mathrm{L}$ & 631.2 \\
\hline
\end{tabular}

solution at a concentration of $3750 \mathrm{ppm}$. Actual concentration of $\mathrm{H}_{2} \mathrm{O}_{2}$ solution was determined by titration method using standardizing solution $(0.1 \mathrm{~N})$ of potassium permanganate $\left(\mathrm{KMNO}_{4}\right)$.

Ozone oxidation was facilitated by ozone generator model C-Lasky C-L1010 (Air Tree Ozone Technology Co., Taiwan). The unit can produce $\mathrm{O}_{3}$ at the rate of $10 \mathrm{~g} \mathrm{~h}^{-1}$ if pure oxygen is used while at $2 \mathrm{~g} \mathrm{~h}^{-1}$ if air is used at flow rate of $6 \mathrm{~L} \mathrm{~min}^{-1}\left(25^{\circ} \mathrm{C}\right)$. Stock solution of $\mathrm{O}_{3}$ in water $(30 \mathrm{ppm})$ was prepared on daily basis. The amount of ozone dissolved in the aqueous phase was determined by indigo method by Hoigne and Bader [19]. Ozone was spiked into previously MTBEbenzene spiked waters at concentrations of 1 and $5 \mathrm{ppm}$.

2.2. UV Photoreactor. Spiked water samples $(500 \mathrm{~mL})$ with MTBE and benzene were transferred to the bench-scale UV photoreactor (Figure 1) (NORMAG Co., Hessenstraße, Hofheim, Germany). Two types of ultraviolet lamps were housed in the photoreactor: (i) $15 \mathrm{~W}$ low pressure (LP) $\mathrm{Hg}$ lamp which emits light at $254 \mathrm{~nm}$ with intensity of $6.5 \times$ $10^{-3} \mathrm{~W} / \mathrm{cm}^{2}$ and (ii) $150 \mathrm{~W}$ medium pressure (MP) Hg lamp which emits light at a wider spectrum ranging from 200 to $400 \mathrm{~nm}$ with intensity of $5.3 \times 10^{-2} \mathrm{~W} \mathrm{~cm}^{-2}$. Due to volatile nature of MTBE and benzene, the temperature of solutions was kept constant at room temperature during treatment.

2.3. Experimental Layout. Three separate sets of experiments were designed for each type of spiked water.

(I) In the first set of experiments, MTBE-benzene spiked waters were treated with two levels of each of $\mathrm{H}_{2} \mathrm{O}_{2}$ (20 and $100 \mathrm{ppm}), \mathrm{O}_{3}$ (1 and $5 \mathrm{ppm}$ ), and UV radiation 


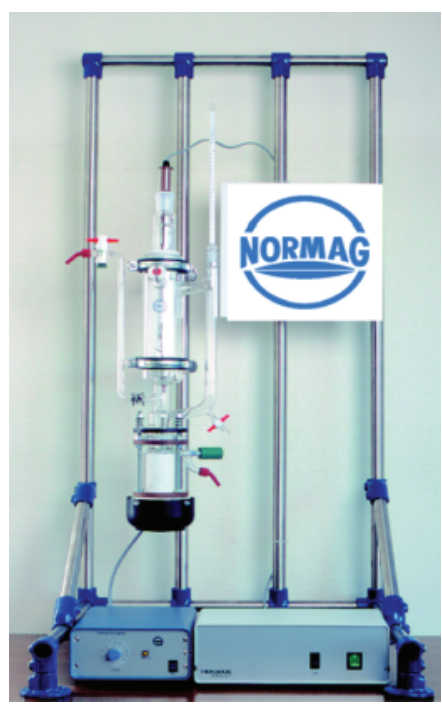

FIgURE 1: The NORMAG photoreactor.

(LP and MP). Separate experiments were performed with each treatment.

(II) In the second set of experiments, MTBE-benzene spiked waters were treated with a combination of different concentrations of $\mathrm{H}_{2} \mathrm{O}_{2}$ (20 and 100 ppm) and UV radiation (254 and $600 \mathrm{~nm}$ ).

(III) In the third set of experiments, MTBE-benzene spiked waters were treated with a combination of different concentrations of $\mathrm{O}_{3}$ (1 and $5 \mathrm{ppm}$ ) and UV radiation (LP and MP).

In all treatments, water samples were collected after runtimes of $0,5,10,20$, and $30 \mathrm{~min}$ and analyzed for residual amount of MTBE, benzene, and by-products. During the rigorous bench-scale testing of the process, operational factors such as concentration of $\mathrm{H}_{2} \mathrm{O}_{2}$ and $\mathrm{O}_{3}$ and contact time were optimized for the removal of MTBE and benzene.

2.4. Chemical Analyses of Samples. Effluent samples from the UV photoreactor were collected periodically and analyzed for its concentration levels of MTBE and benzene using an ISQ single quadrupole GC/MS system (Thermo Scientific) equipped with TriPlus for headspace injection system. A $60 \mathrm{~m}$ long, 0.32 mm i.d. Rtx-502.2 (Restek Corp., USA) capillary column was used for the separation purpose. The carrier gas was helium flowing at the rate of $1.7 \mathrm{~mL} \mathrm{~min}^{-1}$. The column temperature was programmed to rise from 50 to $220^{\circ} \mathrm{C}$ at the rate of $20^{\circ} \mathrm{C} \mathrm{min}^{-1}$. The mass spectrometer was operated in the selected ion mode (SIM). Calibration curves were prepared for MTBE and benzene and some by-products.

2.5. Calculation of EEO Values for $U V / H_{2} \mathrm{O}_{2}$ and $U V / O_{3}$. Electrical energy per order (EEO) of contaminant provides a convenient way to assess the effectiveness of removal of various organic compounds for a given water sample using UV irradiation. It is estimated in terms of $\mathrm{kWh} / 1000$ gal/order of removal, which is determined at the optimum

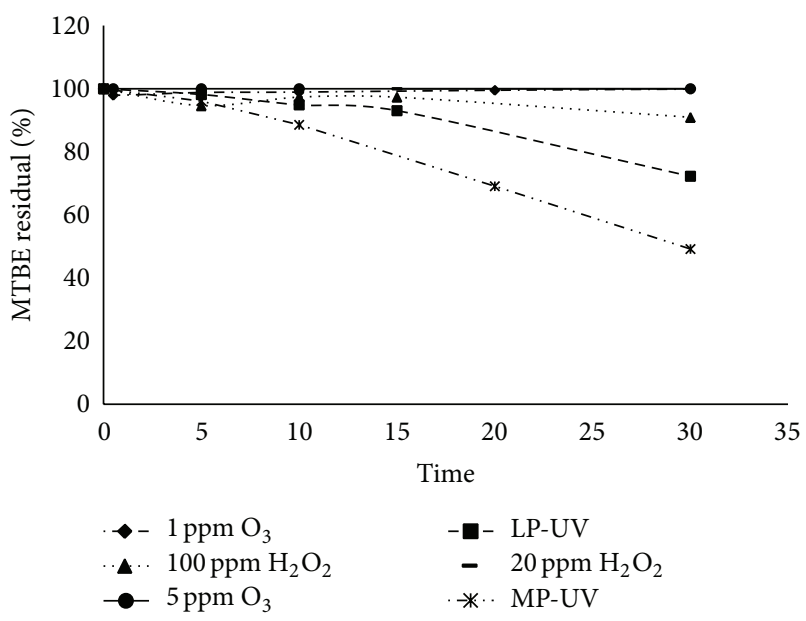

FIgure 2: Removal of MTBE using $\mathrm{H}_{2} \mathrm{O}_{2}, \mathrm{O}_{3}$, and UV only.

$\mathrm{H}_{2} \mathrm{O}_{2}$ or $\mathrm{O}_{3}$ concentrations. Higher values of EEO of a contaminant indicate that the contaminant is more difficult to remove [20]. The EEO $\left(\mathrm{kWh} / \mathrm{m}^{3} /\right.$ order$)$ was calculated from the following equation:

$$
\mathrm{EEO}=\frac{P \times t \times 1000}{V \times 60 \times \log \left(C_{i} / C_{f}\right)},
$$

where $P$ is the power input $(\mathrm{kW}), t$ is the irradiation time ( $\min ), V$ is the volume (L) of the water in the reactor, and $C_{i}$ and $C_{f}$ are the initial and final pollutant concentrations. For one order of removal, concentration should be reduced to $C_{i} / C_{f}=10$ and $\log \left(C_{i} / C_{f}\right)$ would be equal to 1 [21].

\section{Results and Discussion}

3.1. Treatment of MTBE-Benzene Spiked Waters by $\mathrm{H}_{2} \mathrm{O}_{2}, \mathrm{O}_{3}$, or UV Alone. As listed in Table 1, the chemical analyses of groundwater revealed its brackish nature with a total of dissolved solids of over $3600 \mathrm{ppm}$. Moreover, levels of chloride, bromide, and sulfate ions are on the higher side at $1220,4.2$, and $546 \mathrm{ppm}$, respectively. High levels of these anions were expected to compete with the target pollutants (MTBE and benzene) for the hydroxyl radicals [22-25]. In addition, the effect of water quality on the UV exposure and irradiation efficiency is low due to the low turbidity level of 0.1 NTU. The scavenging activities of the anions especially chlorides, carbonates, bicarbonate, and other species has also been reported by other researchers [23, 25]. Classical Fenton's system also supports this behavior of anionic species in terms of nonproductive reactions [23, 26, 27].

Figures 2 and 3 show that both $\mathrm{H}_{2} \mathrm{O}_{2}$ and $\mathrm{O}_{3}$ were not able to influence the removal of MTBE or benzene from contaminated groundwater under the conditions used in the study. This can be attributed to the strong bonding within molecular structure of MTBE and benzene [28, 29]. The second reason could be the relatively low oxidative potential of $\mathrm{H}_{2} \mathrm{O}_{2}$ and $\mathrm{O}_{3}$ [30]. 


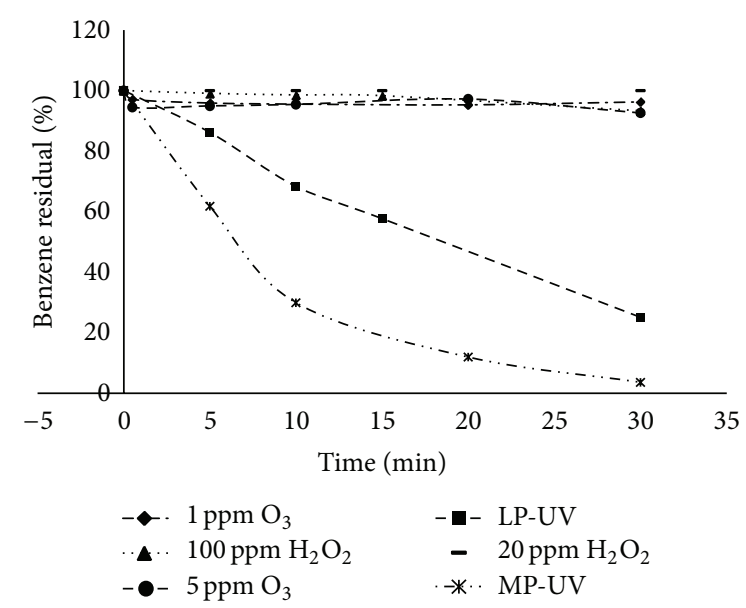

FIgure 3: Removal of benzene using $\mathrm{H}_{2} \mathrm{O}_{2}, \mathrm{O}_{3}$, and UV alone.

However, significant removal of MTBE was observed when the spiked water was treated by UV radiation. Approximately, 50\% of MTBE was removed within 30 minutes of exposure to $150 \mathrm{~W}$ MP UV lamp and about $30 \%$ in samples exposed to $15 \mathrm{~W}$ LP UV lamp. These findings support the results of previously conducted studies that reported partial degradation of MTBE by UV photolysis [31].

Similarly, removal of benzene was substantial in samples exposed to UV photolysis (Figure 3). Approximately 75\% of benzene was removed by $15 \mathrm{~W}$ LP-UV lamp within 30 minutes and $95 \%$ benzene was removed by $150 \mathrm{~W}$ MP-UV irradiation. This accelerated removal of benzene was apparently due to the fact that benzene is slightly less stable against UV radiation than MTBE [32].

3.2. Treatment of MTBE-Benzene Spiked Waters by $U V / H_{2} \mathrm{O}_{2}$ Process. Results of remediation of MTBE-benzene spiked waters by $\mathrm{UV} / \mathrm{H}_{2} \mathrm{O}_{2}$ process are presented in Figures 4 and 5. Removal of the MTBE by $\mathrm{UV} / \mathrm{H}_{2} \mathrm{O}_{2}$ was significantly enhanced as compared to removal by $\mathrm{H}_{2} \mathrm{O}_{2}$ or UV alone (Figure 4). All four possible combinations of UV types (15 W LP and $150 \mathrm{~W} \mathrm{MP)} \mathrm{and} \mathrm{H}_{2} \mathrm{O}_{2}$ concentrations (20 and $100 \mathrm{ppm}$ ) were tested, namely, (i) LP/20 ppm, (ii) LP/100 ppm, (iii) $\mathrm{MP} / 20 \mathrm{ppm}$, (iv) and $\mathrm{MP} / 100 \mathrm{ppm}$. The removal efficacy was found to be influenced by the concentration of $\mathrm{H}_{2} \mathrm{O}_{2}$ as well as by the intensity of UV radiation. With highest removal efficiency at MP/100 $\mathrm{ppm}$ and LP/100 ppm followed by $\mathrm{MP} / 20 \mathrm{ppm}$ and $\mathrm{LP} / 20 \mathrm{ppm}$, the concentration of $\mathrm{H}_{2} \mathrm{O}_{2}$ seems to be the dominating factor as irradiating with both LPUV and MP-UV lamps removed $>95 \%$ of MTBE at $100 \mathrm{ppm}$ $\mathrm{H}_{2} \mathrm{O}_{2}$ within 20 minutes of exposure (Figure 4). Results of this study are consistent with previous studies that have also reported additive effect of coupled $\mathrm{UV} / \mathrm{H}_{2} \mathrm{O}_{2}$ techniques in removal of MTBE from contaminated waters [33].

Similarly, superior efficacy for benzene removal was observed in samples treated with $\mathrm{UV} / \mathrm{H}_{2} \mathrm{O}_{2}$ process compared to the samples treated separately with $\mathrm{UV}$ and $\mathrm{H}_{2} \mathrm{O}_{2}$ (Figure 5). Benzene was completely removed within $10 \mathrm{~min}$ by all four possible combinations of UV intensities (LP and MP)

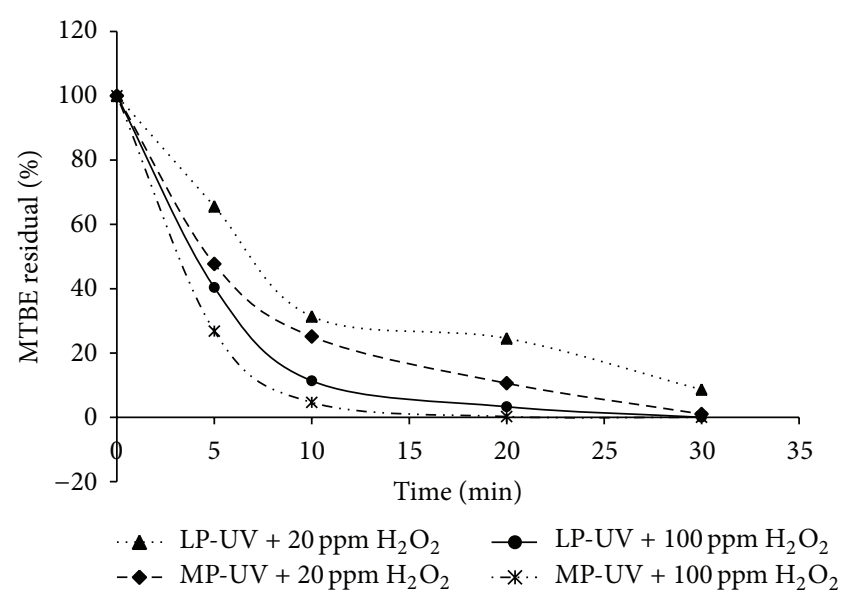

Figure 4: Removal of MTBE using $\mathrm{UV} / \mathrm{H}_{2} \mathrm{O}_{2}$ process.

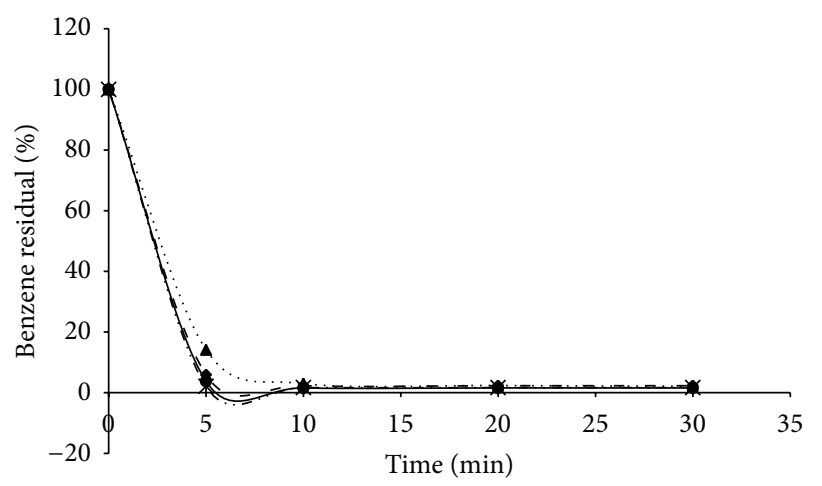

^. LP-UV +20 ppm $\mathrm{H}_{2} \mathrm{O}_{2} \longrightarrow \mathrm{LP}-\mathrm{UV}+100 \mathrm{ppm} \mathrm{H}_{2} \mathrm{O}_{2}$ $-\bullet \mathrm{MP}-\mathrm{UV}+20 \mathrm{ppm} \mathrm{H}_{2} \mathrm{O}_{2} \quad$-*. $\quad \mathrm{MP}-\mathrm{UV}+100 \mathrm{ppm} \mathrm{H}_{2} \mathrm{O}_{2}$

FIgURE 5: Removal of benzene using $\mathrm{UV} / \mathrm{H}_{2} \mathrm{O}_{2}$ process.

and $\mathrm{H}_{2} \mathrm{O}_{2}$ concentrations (20 and $100 \mathrm{ppm}$ ). More than $95 \%$ of benzene was removed within 5 minutes of treatment time in $\mathrm{MP} / 100 \mathrm{ppm}$ and $\mathrm{LP} / 100 \mathrm{ppm}$. Hence, use of $\mathrm{UV} / \mathrm{H}_{2} \mathrm{O}_{2}$ is one of the most efficient methods for remediation of benzene contaminated water. It would be interesting to compare benzene removal by this treatment with alternative remediation methods, such as air stripping and activated carbon adsorption. These results are in tendon with earlier studies in which the successful degradation of benzene using $\mathrm{UV} / \mathrm{H}_{2} \mathrm{O}_{2}$ coupled reactions has been reported [14].

\subsection{Treatment of MTBE-Benzene Spiked Waters by $\mathrm{UV} / \mathrm{O}_{3}$} Process. This study was designed to evaluate combined effect of UV irradiation and ozone oxidation $\left(\mathrm{UV} / \mathrm{O}_{3}\right)$ on remediation of MTBE-benzene spiked waters. Again, all four possible combinations of UV intensities (LP and MP) and $\mathrm{O}_{3}$ concentrations ( 1 and $5 \mathrm{ppm}$ ) were tested, namely, (i) $\mathrm{LP} / 1 \mathrm{ppm}$, (ii) LP/5 ppm, (iii) MP/1 ppm, (iv) and MP/5 ppm. Results of the experiment are shown in Figures 5 and 6.

Remediated process seemed to be influenced mainly by $\mathrm{O}_{3}$ concentration as maximum removal of MTBE was recorded in the samples treated with $\mathrm{MP} / 5 \mathrm{ppm} \mathrm{O}_{3}$ as $80 \%$ 


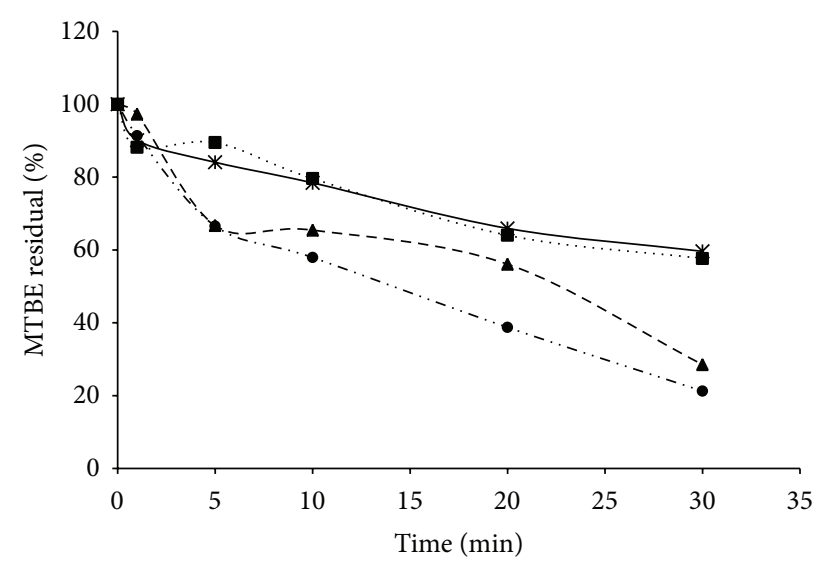

... LP-UV $+1 \mathrm{ppm} \mathrm{O}_{3} \quad * \quad \mathrm{LP}-\mathrm{UV}+5 \mathrm{ppm} \mathrm{O}_{3}$ $-\mathbf{\Delta}-\mathrm{MP}-\mathrm{UV}+1 \mathrm{ppm} \mathrm{O}_{3} \quad \longrightarrow \quad \mathrm{MP}-\mathrm{UV}+5 \mathrm{ppm} \mathrm{O}_{3}$

Figure 6: Removal of MTBE using $\mathrm{UV} / \mathrm{O}_{3}$ process.

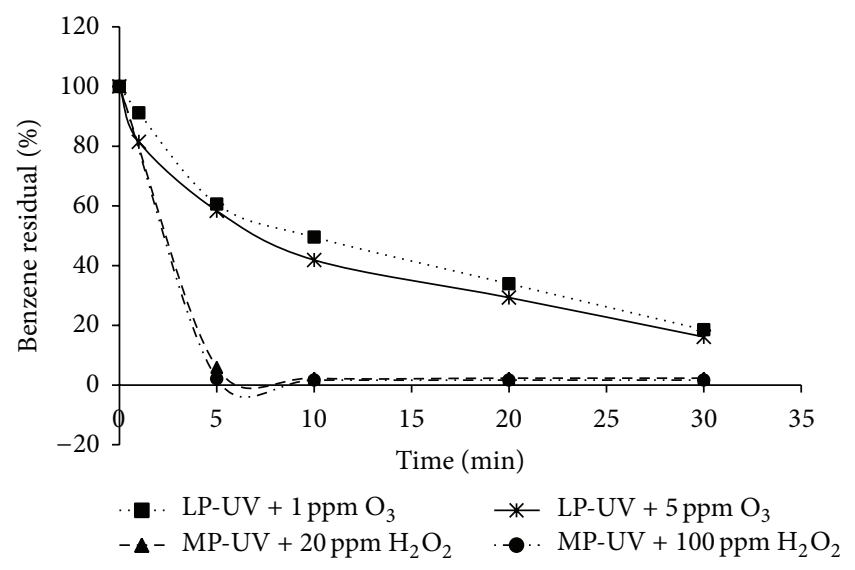

FIgURE 7: Removal of benzene using $\mathrm{UV} / \mathrm{O}_{3}$ process.

followed by $\mathrm{LP} / 5 \mathrm{ppm} \mathrm{O}_{3}$ as $70 \%$ in $30 \mathrm{~min}$, while only a little amount of MTBE (40\%) was removed at $1 \mathrm{ppm}$ of $\mathrm{O}_{3}$ concentration in both LP and MP treated samples (Figure 6).

Benzene removal by $\mathrm{UV} / \mathrm{O}_{3}$ process was chiefly influenced by the type of UV radiation (Figure 7) as more than $95 \%$ of benzene was removed after 30 minutes in samples treated with $\mathrm{MP} / 5 \mathrm{ppm}$ and $\mathrm{MP} / 1 \mathrm{ppm}$ compared to $80 \%$ removal in samples treated with $\mathrm{LP} / 1 \mathrm{ppm}$ and $\mathrm{LP} / 5 \mathrm{ppm}$. Hence, removal of benzene was superior at higher UV intensities.

Results of the remediation assays clearly demonstrate superiority of using MP over LP radiation and $\mathrm{H}_{2} \mathrm{O}_{2}$ over $\mathrm{O}_{3}$ in an AOP. In all studied treatments benzene was removed relatively quickly compared to MTBE. Hence, MTBE may become a slight limiting factor when both contaminants are treated simultaneously by AOPs.

The MTBE degradation by $\mathrm{UV} / \mathrm{H}_{2} \mathrm{O}_{2}$ process is demonstrated by the formation of by-products (i.e., tertiary butyl formate (TBF) and tertiary butyl alcohol (TBA)) as presented in Figure 8 which shows the formation of TBF and TBA when MTBE is treated with LPUV lamp with $50 \mathrm{ppm}_{2} \mathrm{O}_{2}$.

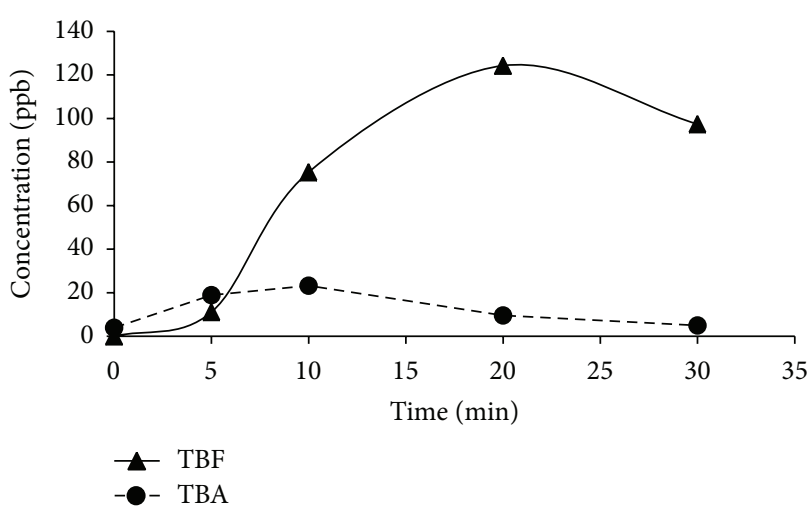

FIGURE 8: By-products formed due to degradation of MTBE.

TABLE 2: The EEO values for MTBE and benzene by LP-UV and MP$\mathrm{UV}$ at $100 \mathrm{ppm}$ of $\mathrm{H}_{2} \mathrm{O}_{2}$.

\begin{tabular}{lcc}
\hline Process & Pollutant & EEO = KW·hr/1000 gal \\
\hline LP-UV-100 ppm $\mathrm{H}_{2} \mathrm{O}_{2}$ & MTBE & 21.03 \\
LP-UV-100 ppm $\mathrm{H}_{2} \mathrm{O}_{2}$ & Benzene & 6.31 \\
MP-UV-100 ppm $\mathrm{H}_{2} \mathrm{O}_{2}$ & MTBE & 15.77 \\
MP-UV-100 ppm $\mathrm{H}_{2} \mathrm{O}_{2}$ & Benzene & 8.41 \\
\hline
\end{tabular}

3.4. The EEO for Benzene Removal by $U V / H_{2} \mathrm{O}_{2}$. The optimum conditions for removal of MTBE using the $15 \mathrm{~W}$ LP-UV lamp were peroxide $\left(\mathrm{H}_{2} \mathrm{O}_{2}\right)$ of $100 \mathrm{ppm}$ (Figure 4). Table 2 summarizes the calculations of the EEO values for MTBE and benzene when treating contaminated groundwater and reducing the concentration of MTBE and benzene by 10 orders of magnitude using both LP $15 \mathrm{~W}$ and MP $150 \mathrm{~W}$ combined with $100 \mathrm{ppm}_{2} \mathrm{O}_{2}$. From the data in Table 2, it is estimated that 10 and 2 minutes are needed to irradiate the water spiked with MTBE and benzene, respectively, when using LP-UV+ $100 \mathrm{ppm}_{2} \mathrm{O}_{2}$. The values of EEO for MTBE and benzene are $21 \mathrm{~kW} \cdot \mathrm{hr} / 1000 \mathrm{gal}$ and $6.3 \mathrm{~kW} \cdot \mathrm{hr} / 1000 \mathrm{gal}$, respectively, while the EEO values for the 2 contaminants calculated for the $150 \mathrm{~W}$ MP-UV lamp were 15.7 and 8.41, respectively. Hence, benzene is relatively easier to remove from water. These results are slightly higher than the EEO levels reported in previously published work (Calgon AOT Handbook, 1996) which stated EEO values of $10 \mathrm{kWh} / 1000$ gal for MTBE and $2-5 \mathrm{kWh} / 1000$ gal for benzene. The main reason for the high values of EEO is attributed to the quality of the groundwater treated which consists of high levels of radical scavengers as discussed above.

The EEO values for MTBE removal by $\mathrm{UV} / \mathrm{O}_{3}$ process were not calculated since 10 orders of removal of MTBE were not attained within the 30 minutes of reaction time used in the study.

\section{Conclusion}

Both MTBE and benzene can be removed simultaneously from contaminated water using advanced oxidation processes employing different combinations of UV, $\mathrm{H}_{2} \mathrm{O}_{2}$, and $\mathrm{O}_{3}$. Remediation assays clearly demonstrate superiority of 
using MP over LP radiation and $\mathrm{H}_{2} \mathrm{O}_{2}$ over $\mathrm{O}_{3}$. Superiority of using $\mathrm{UV} / \mathrm{H}_{2} \mathrm{O}_{2}$ over $\mathrm{UV} / \mathrm{O}_{3}$ process and also its efficiency in removing benzene as compared to MTBE, from contaminated water, were established. It was also confirmed by lower EEO values for $\mathrm{UV} / \mathrm{H}_{2} \mathrm{O}_{2}$ as compared to that of $\mathrm{UV} / \mathrm{O}_{3}$. The efficacy of these processes clearly depends upon the concentrations of $\mathrm{H}_{2} \mathrm{O}_{2}$ and $\mathrm{O}_{3}$ and intensity of $\mathrm{UV}$ radiation. Furthermore, benzene was comparatively easier to degrade than MTBE. Hence, MTBE may become a slight limiting factor when both contaminants are targeted simultaneously. Detailed studies are required to unearth exact mechanism behind variable behaviors of benzene and MTBE towards AOPs.

\section{Conflict of Interests}

The author declares that there is no conflict of interests regarding the publication of this paper.

\section{Acknowledgments}

This study was funded by King Abdulaziz City for Science and Technology (KACST) under Project no. AR-29-110. The author is also thankful to the management of King Fahd University of Petroleum and Minerals for their support in this study.

\section{References}

[1] M. Rosell, S. Lacorte, and D. Barceló, "Analysis, occurrence and fate of MTBE in the aquatic environment over the past decade," TrAC Trends in Analytical Chemistry, vol. 25, no. 10, pp. 10161029, 2006.

[2] T. T. Tang, Q. Z. Wei, X. W. Peng et al., "Characteristics of atmospheric methyl tert-butyl ether (MTBE) in summer in Shenzhen, China," Applied Mechanics and Materials, vol. 522, pp. 84-87, 2014.

[3] C. L. Patterson, F. Cadena, R. Sinha, D. K. Ngo-Kidd, A. Ghassemi, and E. Radha Krishnan, "Field treatment of MTBE-contaminated groundwater using ozone/UV oxidation," Groundwater Monitoring \& Remediation, vol. 33, no. 2, pp. 44-52, 2013.

[4] C. Sellers, "From poison to carcinogen: towards a global history of concerns about benzene," Global Environment, vol. 7, no. 1, pp. 38-71, 2014.

[5] E. C. Souza, T. C. Vessoni-Penna, and R. P. de Souza Oliveira, "Biosurfactant-enhanced hydrocarbon bioremediation: an overview," International Biodeterioration \& Biodegradation, vol. 89, pp. 88-94, 2014.

[6] M. K. Mukhopadhyay and D. Nath, "Physiologically based toxicokinetic modeling of secondary acute myelolytic leukemia," Environmental Toxicology and Pharmacology, vol. 37, no. 1, pp. 378-389, 2014.

[7] H. Vatani and A. S. Yazdi, "Ionic-liquid-mediated poly(dimethylsiloxane)-grafted carbon nanotube fiber prepared by the sol-gel technique for the head space solid-phase microextraction of methyl tert-butyl ether using GC," Journal of Separation Science, vol. 37, no. 1-2, pp. 127-134, 2014.

[8] T. C. Shih, M. Wangpaichitr, and M. Suffet, "Evaluation of granular activated carbon technology for the removal of methyl tertiary butyl ether (MTBE) from drinking water," Water Research, vol. 37, no. 2, pp. 375-385, 2003.

[9] I. Levchuk, A. Bhatnagar, and M. Sillanpää, “Overview of technologies for removal of methyl tert-butyl ether (MTBE) from water," Science of the Total Environment, vol. 476-477, pp. 415433, 2014.

[10] H. Rizvi, N. Ahmad, A. Yasar, K. Bukhari, and H. Khan, "Disinfection of UASB-treated municipal wastewater by $\mathrm{H}_{2} \mathrm{O}_{2}, \mathrm{UV}$, Ozone, PAA, $\mathrm{H}_{2} \mathrm{O}_{2}$ /sunlight, and advanced oxidation processes: regrowth potential of pathogens," Polish Journal of Environmental Studies, vol. 22, no. 4, p. 1153, 2013.

[11] M. Swaminathan, M. Manickavachagam, and M. Sillanpaa, "Advanced oxidation processes for wastewater treatment 2013," International Journal of Photoenergy, vol. 2014, Article ID 682767, 2 pages, 2014.

[12] A. Asadi and M. Mehrvar, "Degradation of aqueous methyl tertbutyl ether by photochemical, biological, and their combined processes," International Journal of Photoenergy, vol. 2006, Article ID 19790, 7 pages, 2006.

[13] N. N. Mahamuni and Y. G. Adewuyi, "Advanced oxidation processes (AOPs) involving ultrasound for waste water treatment: a review with emphasis on cost estimation," Ultrasonics Sonochemistry, vol. 17, no. 6, pp. 990-1003, 2010.

[14] M. Bahmani, V. Bitarafhaghighi, K. Badr, P. Keshavarz, and D. Mowla, "The photocatalytic degradation and kinetic analysis of BTEX components in polluted wastewater by $\mathrm{UV} / \mathrm{H}_{2} \mathrm{O}_{2}$-based advanced oxidation," Desalination and Water Treatment, vol. 52, no. 16-18, pp. 3054-3062, 2014.

[15] C.-H. Hung, "Advanced oxidation of methyl tert-butyl ether (MTBE) by $\mathrm{UV} / \mathrm{TiO}_{2}$ and $\mathrm{H}_{2} \mathrm{O}_{2}-\mathrm{UV} / \mathrm{TiO}_{2}$ processes," Water Science and Technology: Water Supply, vol. 6, no. 2, pp. 77-85, 2006.

[16] H. Huang, X. Ye, H. Huang, P. Hu, L. Zhang, and D. Y. Leung, "Photocatalytic oxidation of gaseous benzene under $185 \mathrm{~nm}$ UV irradiation," International Journal of Photoenergy, vol. 2013, Article ID 890240, 6 pages, 2013.

[17] Z. Zhu, X. Li, Q. Zhao et al., "FTIR study of the photocatalytic degradation of gaseous benzene over UV-irradiated $\mathrm{TiO}_{2}$ nanoballs synthesized by hydrothermal treatment in alkaline solution," Materials Research Bulletin, vol. 45, no. 12, pp. 18891893, 2010.

[18] L.-T. Hsieh, H.-H. Yang, and H.-W. Chen, "Ambient BTEX and MTBE in the neighborhoods of different industrial parks in Southern Taiwan," Journal of Hazardous Materials, vol. 128, no. 2-3, pp. 106-115, 2006.

[19] H. Hoigne and H. Bader, "Rate constants of reactions of ozone with organic and inorganic compounds in water. II. Dissociating organic compounds," Water Research, vol. 17, no. 2, pp. 185-194, 1983.

[20] K. Li, D. R. Hokanson, J. C. Crittenden, R. R. Trussell, and D. Minakata, "Evaluating $\mathrm{UV} / \mathrm{H}_{2} \mathrm{O}_{2}$ processes for methyl tertbutyl ether and tertiary butyl alcohol removal: effect of pretreatment options and light sources," Water Research, vol. 42, no. 20, pp. 5045-5053, 2008.

[21] N. Daneshvar, A. Aleboyeh, and A. R. Khataee, "The evaluation of electrical energy per order $\left(E_{E o}\right)$ for photooxidative decolorization of four textile dye solutions by the kinetic model," Chemosphere, vol. 59, no. 6, pp. 761-767, 2005.

[22] J. De Laat, G. Truong Le, and B. Legube, "A comparative study of the effects of chloride, sulfate and nitrate ions on the rates of decomposition of $\mathrm{H}_{2} \mathrm{O}_{2}$ and organic compounds by 
$\mathrm{Fe}(\mathrm{II}) / \mathrm{H}_{2} \mathrm{O}_{2}$ and $\mathrm{Fe}(\mathrm{III}) / \mathrm{H}_{2} \mathrm{O}_{2}$," Chemosphere, vol. 55, no. 5, pp. 715-723, 2004.

[23] B. G. Kwon, D. S. Lee, N. Kang, and J. Yoon, "Characteristics of p-chlorophenol oxidation by Fenton's reagent," Water Research, vol. 33, no. 9, pp. 2110-2118, 1999.

[24] B. G. Petri, R. J. Watts, A. L. Teel, S. G. Huling, and R. A. Brown, "Fundamentals of ISCO using hydrogen peroxide," in In Situ Chemical Oxidation For Groundwater Remediation, pp. 33-88, Springer, 2011.

[25] X.-Y. Yu and J. R. Barker, "Hydrogen peroxide photolysis in acidic aqueous solutions containing chloride ions. I. Chemical mechanism," Journal of Physical Chemistry A, vol. 107, no. 9, pp. 1313-1324, 2003.

[26] F. J. Beltrán, M. González, F. J. Rivas, and P. Alvarez, "Fenton reagent advanced oxidation of polynuclear aromatic hydrocarbons in water,' Water, Air, and Soil Pollution, vol. 105, no. 3-4, pp. 685-700, 1998.

[27] E. Lipczynska-Kochany, G. Sprah, and S. Harms, "Influence of some groundwater and surface waters constituents on the degradation of 4-chlorophenol by the Fenton reaction," Chemosphere, vol. 30, no. 1, pp. 9-20, 1995.

[28] R. Janoschek, "Has the benzene molecule an extra stability?" Journal of Molecular Structure, vol. 229, pp. 197-203, 1991.

[29] B. E. Riitmann, "Applying NRC guidelines for natural attenuation of MTBE," Soil and Sediment Contamination, vol. 11, no. 5, pp. 687-700, 2002.

[30] W. H. Glaze and J.-W. Kang, "Advanced oxidation processes. Description of a kinetic model for the oxidation of hazardous materials in aqueous media with ozone and hydrogen peroxide in a semibatch reactor," Industrial and Engineering Chemistry Research, vol. 28, no. 11, pp. 1573-1580, 1989.

[31] B. Tawabini, N. Fayad, and M. Morsy, "The impact of groundwater quality on the removal of methyl tertiary-butyl ether (MTBE) using advanced oxidation technology," Water Science and Technology, vol. 60, no. 8, pp. 2161-2165, 2009.

[32] M. M. Mitani, A. A. Keller, C. A. Bunton, R. G. Rinker, and O. C. Sandall, "Kinetics and products of reactions of MTBE with ozone and ozone/hydrogen peroxide in water," Journal of Hazardous Materials, vol. 89, no. 2-3, pp. 197-212, 2002.

[33] R. Alnaizy and T. H. Ibrahim, "MTBE removal from contaminated water by the $\mathrm{UV} / \mathrm{H}_{2} \mathrm{O}_{2}$ process," Desalination and Water Treatment, vol. 10, no. 1-3, pp. 291-297, 2009. 

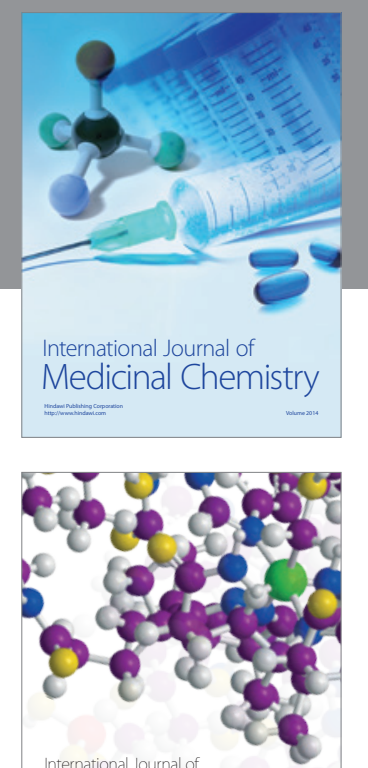

\section{Carbohydrate} Chemistry

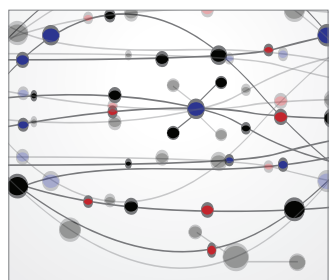

The Scientific World Journal
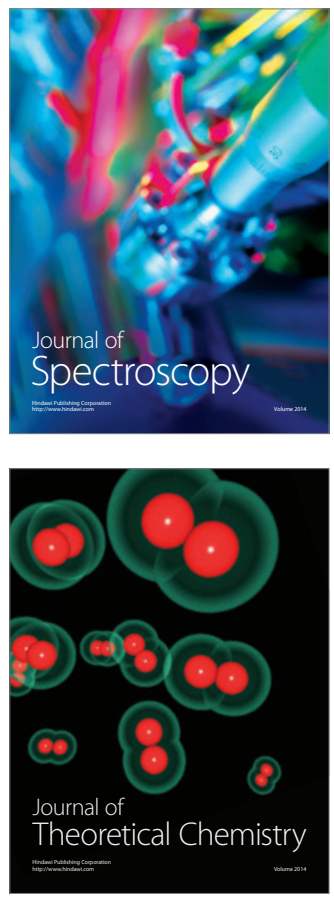
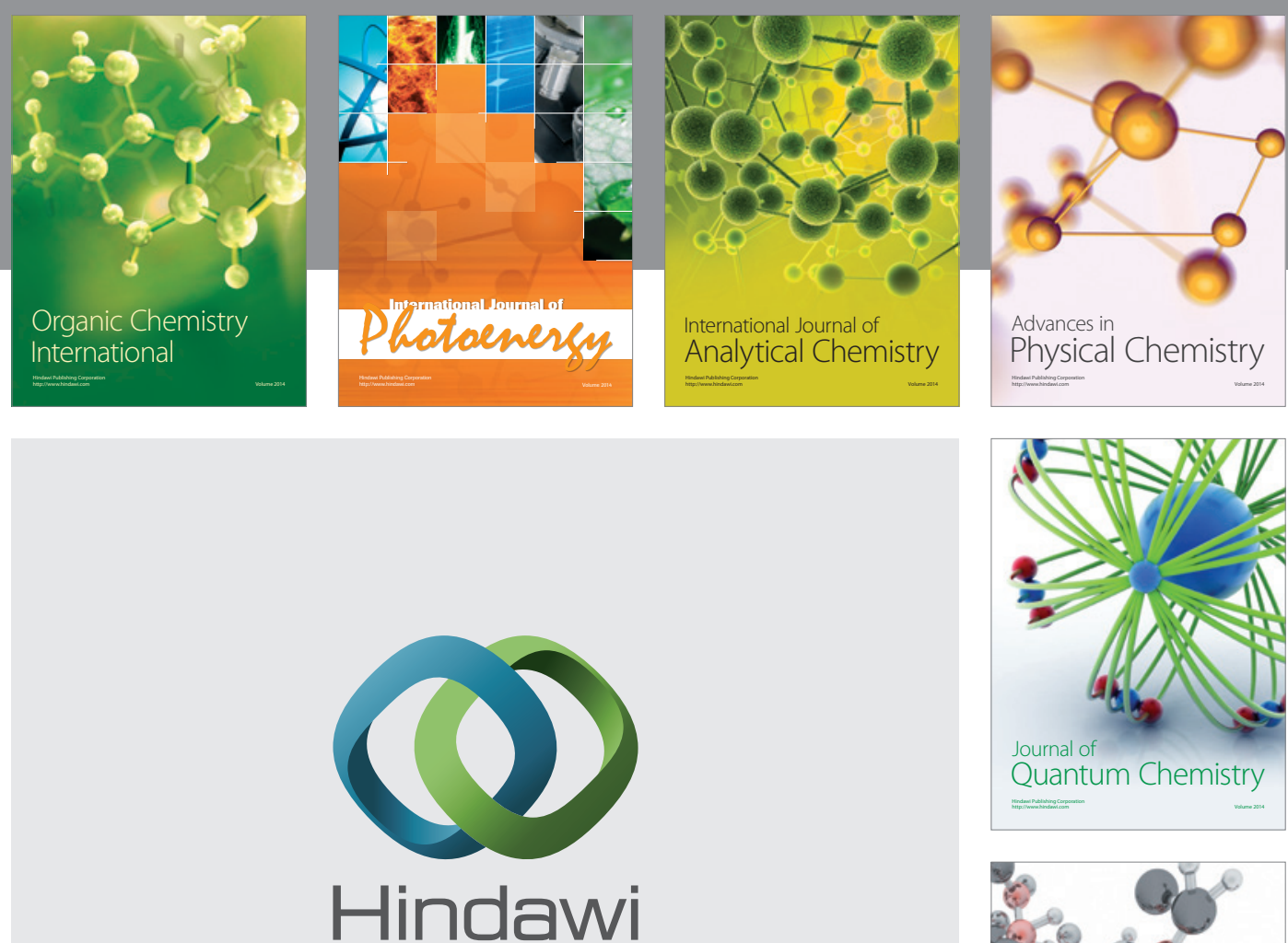

Submit your manuscripts at

http://www.hindawi.com

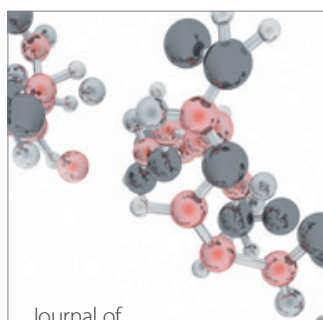

Analytical Methods

in Chemistry

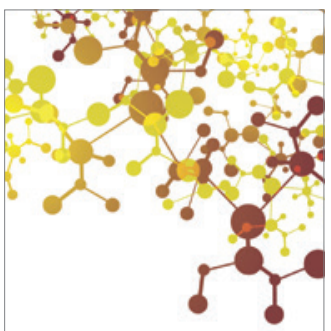

Journal of

Applied Chemistry

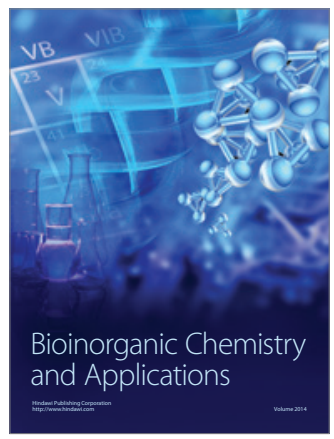

Inorganic Chemistry
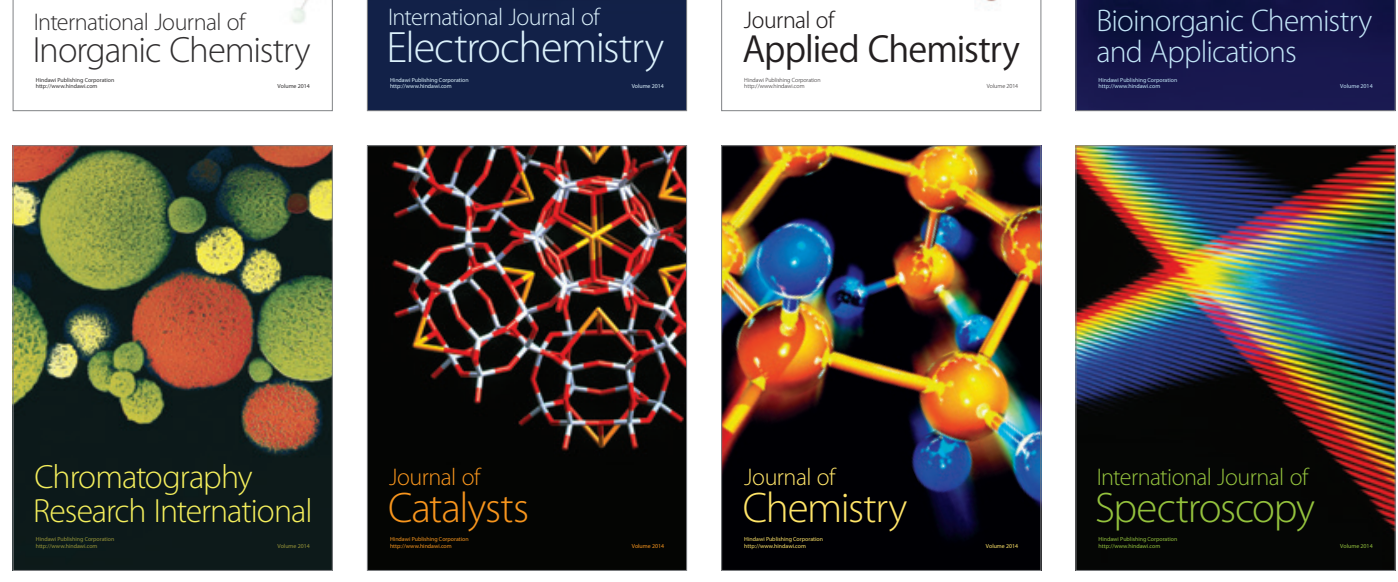